\title{
Metamorphoses Analysis of Juno's Revenge on Her Rivals in Love in Ovid's Metamorphoses in the Light of Data Analysis and Defamiliarization
}

\author{
Xiaohui Sui ${ }^{1, *}$ \\ ${ }^{1}$ School of Liberal Education, Jinan Engineering Polytechnic, Jinan, Shandong, 250014, China \\ *Corresponding author. Email: xiaohuisui@163.com
}

\begin{abstract}
This paper aims at interpreting Juno's revenge stories in Ovid's Metamorphoses in the light of defamiliarization and data analysis. Through defamiliarization as well as data analysis on the times, objects, subjects and connotations of metamorphoses, this paper restores a series of metamorphoses stories into marriage defences of a wife. Marriage ethic is also dealt with from different aspects in this paper.

Keywords: metamorphoses, data analysis, defamiliarization, revenge on rivals in love
\end{abstract}

\section{INTRODUCTION}

In Ovid's Metamorphoses, gods and goddess could turn mortals into things and animals at their will, and at the same time, they could change their forms and turn to what they want freely. On the contrary, mortals could only accept the transformation imposed on them passively and often miserably. In ancient myths, Metamorphoses served as a kind of death interpretation for the primitive people. But in Ovid's Metamorphoses, transformation is used as metaphor and it actually is a kind of defamiliarization. The stories of gods in Metamorphoses are actually the stories of human being. According to the viewpoint of Russian formalists, artistic techniques such as defamiliarization estranges or defamiliarizes the materials, frees people from automation and non-conscience and enables readers to experience the novelty of the world, thus arousing people's sensitive perception and aesthetic appreciation. [1] Defamiliarization keeps impeding people's "normal response", wakening people from the numbness and indifference to adjust their psychological mode and appreciate the vividness and richness of the objects with strange eyes.

In this paper, transformation is identical with metamorphosis in meaning. Based on the above-mentioned, it is reasonable to infer that the transformations of Io, Callisto, Jove and Juno in these stories in Ovid's Metamorphoses are actually defamiliarization, a kind of metaphor. Ovid implicitly shows the sufferings of IO and Calisto through metamorphoses. In addition, taking off the surface of metamorphoses and defamiliarization, a series of marriage defences are exposed to readers. Status of wife and husband in marriage, and attitude toward love outside marriage in society can be inferred by carefully interpretation. To analyse metamorphosis, this paper will approach to metamorphoses in three aspects: subject, object and connotation of metamorphoses. The subject refers to the original existence of the metamorphosis; the object refers to the terminal existence of metamorphosis. Connotation means the euphemistical meaning of the metamorphoses.

\section{METAMORPHOSES INTEPRETATION}

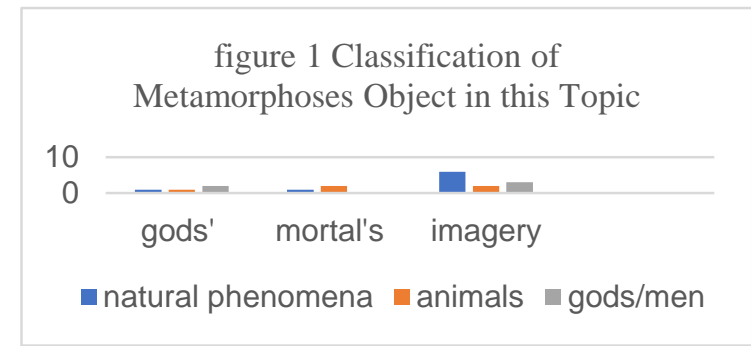

In this topic, there are 18 metamorphoses involved. They fall into three categories: god's, mortal's and imagery, among which imageries don't involve subjects with their connotations stable. Animals are the most frequent objects for god's, mortals and imageries.

\subsection{Metamorphoses Analysis about Io}

When Io was wandering along her father's stream, she was seen and chased by Jove. "Cloaked by a sudden thundercloud, Jove overcome Io's scruple and flight." [2] But Juno noticed Jove was away and suspected the black cloud was Jove's another deception. She dropped to the earth and dismissed the clouds. Wary Jove felt the arrival of Juno and hurriedly turned Io into a milk-white cow. Juno asked Jove for the cow as a gift. After careful consideration, Juno decided to leave Io to the watchful Argos with a hundred eyes which took turns at staying awake and sleeping. Under Argos' supervision, Io was harshly driven. Jove sent his son, Mercury to kill Argos and free Io. Mercury succeeded by hypnotizing the monster with stories, pipe music and his magic wand. Juno instructed one of Erinyes to haunt Io. Io ran by day and night under the curse until she reached Nile. Juno's rage grew calm with Jove's promise not to think of Io any longer. Then Io became 
human again and regained her speech, giving birth to a son named Epaphus in Egypt.

Table 1 statistical analysis of metamorphoses about Io

\begin{tabular}{|l|l|l|l|l|}
\hline object & cloud & cow & Argos & $\begin{array}{l}\text { The } \\
\text { Furies }\end{array}$ \\
\hline connotation & hideout & $\begin{array}{l}\text { reduced } \\
\text { existence }\end{array}$ & guard & Gossip \\
\hline subject & null & Io & null & null \\
\hline
\end{tabular}

According to formalists, the literary text doesn't just reflect the reality. Instead, it tends to estrange the reality and break the habit people hold to perceive the real world, making the real world the object we re-examine. The cloud was certain means Jove used to conceal his misbehaviour. When faced with Juno, Jove turned Io into a cow who lost her speech and normal looking. It is not difficult to imagine a guilty husband told his wife the young girl he had a love affair with was just a slave for fear of trouble. And to make the best of a mistake, he was forced to give Io to Juno as a gift slave to save further trouble. Juno put Io under severe supervision by someone very cruel and watchful. After Argos, the supervisor, was killed by the messenger of Jove, the inflamed Juno instructed one of Erinyes to haunt Io. Maybe she took advantage of her fame and prestige to defame, condemn and isolate Io, leaving no peace for her day and night until there was a compromise between Jove and Juno. In this story, Erinyes can be seen today as the public opinions or gossip on the immoral love party. This story ends up in Juno's victory, separating Jove and Io and expelling Io to a remote place.

\subsection{Metamorphoses Analysis about Callisto}

In the story of the beautiful Arcadian nymph, Jove fell in love with the beautiful girl Callisto and disguised as his daughter Diana to seduce Callisto because Callisto was one of the Diana's girls-at-arms. When Callisto got bigger and bigger, it was difficult to keep the secret between Jove and her. The secret was finally revealed and Callisto was banished by Diana when Callisto was forced to take a bath together with all the girls after a day's tiring hunting. Juno knew the condition of the poor girl and waited for a time to take revenge on her. Then the time came when Arcas was born. Juno turned Callisto into a bear who haunted the forest with fear. When Arcas reached his fifteen he came across his mother in the forest and, taking her as a bear, poised a spear and aimed at his mother's heart. Jove held back the thrust and swept mother and son into the sky to avoid the tragedy. Juno couldn't bear the fact that Callisto and her son were new constellation in the sky as herself. She went to Tethys and Oceanus and asked them not to allow Callistio as well as her son to enter the ocean when night fell.

Table 2 statistic of metamorphoses about Callisto

\begin{tabular}{|l|l|l|l|}
\hline object & Diana & bear & The Bears/star \\
\hline connotation & $\begin{array}{l}\text { Means of } \\
\text { seduction }\end{array}$ & $\begin{array}{l}\text { reduced } \\
\text { existence }\end{array}$ & $\begin{array}{l}\text { promoted } \\
\text { existence }\end{array}$ \\
\hline subject & Jove & Callisto & $\begin{array}{l}\text { Callisto and } \\
\text { Arcas }\end{array}$ \\
\hline
\end{tabular}

Defamiliarization emphasizes the sensibility of the literary particularity. Instead of reflecting life just like a mirror, art should change life into a strange and fresh resemblance, inspiring readers' perception of life. [3] By Jove's taking the mask of Diana, Ovid described a man who created an illusion to seduce Callisto. Juno's turning Callisto into a bear and separating her from her son might imply destroying a beautiful girl's looking as well as her fame and depriving her of her son. Years later, when Arcas grown up, Juno tried to let Arcas hate and hurt his mother as an alien. Jove couldn't stand seeing the tragedy happening. Turning the mother and son into bears glittering in the sky can be interpreted as Jove's final acknowledgement of the status of Callisto and Arcas and giving them suitable social and material maintenance. Considering this to be a threaten of Juno's status as a queen, Tethys and Oceanus can be the alliance Juno had to repel Callisto and her son in the noble society. By metamorphoses and defamiliarization, Juno's cruelty in her revenge on her rival in love is expressed indirectly and euphemistically. By analysis and decoding the metamorphoses, we can see Callisto's fate was changed from a naïve girl to a mistress of Jove repelled by society and finally to a member of the noble society with her son.

\subsection{Metamorphoses Analysis about Europa}

In the story of Jove and Europa, Jove turned himself into a bull to abduct Europa away from her homeland Phoenicia to Crete. Among Jove's mistresses, Europa was one of the rare lucky ones who didn't experience any transformation. Turning into a bull may mean that Jove pretended to be an honest and good-looking young man in order to approach Europa without arousing her alertness. Jove didn't confess his real identity until they got to the mountainside of Crete, far from Sidon and Greece. Juno had no revenge on Europa, so this story was just a prelude to the tragedies of Cadmus family where all the hatred of Juno fell. 
Table 3 statistical metamorphoses analysis about Europa

\begin{tabular}{|l|l|}
\hline object & bull \\
\hline connotation & Means of seduction \\
\hline subject & Jove \\
\hline
\end{tabular}

\subsection{Metamorphoses Analysis about Semele}

Semele was the daughter of Cadmus, who was sent by his father to look for his sister Europa and was not allowed to return home unless he brought his sister back. Cadmus followed the oracle of Phoebus to go after a white ox he came across and built a city where it stopped. During the process, Cadmus killed the dragon and sowed the teeth of it in the field. Then there sprouted some warriors who fought against each other. The five warriors left helped Cadmus build the city named Thebes. Semele got pregnant with Jove. Furious Juno decided to take revenge. Juno disguised as an old woman and talked Semele into the idea of having Jove prove his love and identity by taking her as he took Juno in heaven, dressed in glory. Jove promised Semele anything she wanted by swear by Styx. He tried to make his power lighter by taking the lesser bolt. Nonetheless, Semele's body couldn't bear the godly heat and love and was burned into ashes. Jove took the baby out of her womb, sewed it in his own thigh and nourished it until its birth. The dragon in this story is most probably a huge serpent living nearby the water. The dragon teeth in Cadmus' case must be certain merit people got when they conquered the serpent. Following Pallas' advice, Cadmus' sowing the teeth in fact was possible that, inspired by martial wit, Cadmus let the local people have the merit which provoked dispute among the people in distributing. The dragon's teeth, serving as origin of disputes, brought warriors out of naïve people. The pregnancy of Semele with Jove added to the hate of Juno on Agenor family. Juno disguised herself as an old woman and assumed the voice of Semele's old nurse. She got the confidence of Semele, and instigated the girls to ask Jove to take her the way Jove took Juno in the heaven. This is no difference from setting fires on herself. The dew, clouds, lightning, thunder, and bolt Jove put on symbolized the ceremonial facilities and the invisible fire was the majesty of a supreme emperor, which were what Semele couldn't bear and caused her early death with a baby in her womb. The premature infant was sewn in Jove's thigh, which refers

Table 4 statistical analysis of metamorphoses about Semele

\begin{tabular}{|l|l|l|l|l|l|l|l|l|l|l|l|}
\hline object & $\begin{array}{l}\text { Dragon's } \\
\text { teeth }\end{array}$ & warriors & Old nurse & $\begin{array}{l}\text { lightning } \\
\text { \& thunder }\end{array}$ & fog & cloud & dew & bolt & $\begin{array}{l}\text { Invisible } \\
\text { fire }\end{array}$ & $\begin{array}{l}\text { Jove's } \\
\text { thigh }\end{array}$ \\
\hline Connotation & merit & people & $\begin{array}{l}\text { Means of } \\
\text { confidence }\end{array}$ & \multicolumn{2}{|l|}{ ceremonial facilities } & majesty & $\begin{array}{l}\text { Paternal } \\
\text { nursery }\end{array}$ \\
\hline subject & null & null & Juno & null & null & null & null & null & null & null & null \\
\hline
\end{tabular}

that Jove nourished the baby in person until he got big enough to be entrusted to his aunt Ino. In figuring out the connotation to these imageries, readers reprocess the story in their mind. In this way, the goals of metamorphoses and defamiliarization are achieved.

\section{MARRIAGE ETHIC}

\subsection{Female's Status in Marriage}

In Ovid's Metamorphoses, the stories of Juno's defence for marriage and her revenge on her rivals in love kept coming up. We can conclude from this fact that women were inferior to men in marriage relationship at that time. On the other hand, Juno had both the will and power to exert severe 
revenges on her rivals in love, either changing them into animals or causing death on them by scheme. As for Jove, his attitude towards Juno's revenge on his mistresses was no other than indulgence. In Io's case, he gave the cow transformed from Io to Juno at her request. Seeing too much of the torture for Io by Argos, Jove secretly sent his son Mercury to kill Argos. When Io was haunted by one of the Furies, Jove could do nothing but plead with Juno for pity for Io. From this aspect, we can infer that Juno as a wife had considerable power in her marriage to counterbalance the power of Jove. Juno's jealousy was not the result of her narrow-mind, but the result of defence for her legal marriage. The deep reason for Juno's revenges is that she wanted to protect the sanctity and chastity of her marriage. What lied behind the revenges of Juno was the revolt and challenge of the authority of husband.[4]

\subsection{Attitude towards Marriage in these Stories}

Juno was goddess of marriage and was seen as the guardian of marriage. Her firm defence of marriage served as evitable attitude toward marriage. For Juno, Jove's betrayal of marriage was always of moment. She always targeted her rivals not her husband as object of revenge because she took Jove's love and Jove as her private property which couldn't be shared and violated by anyone. [5]

Males highly valued marriage too. Although Jove kept beauty hunting and had children with his mistresses, he never vacillated the status of Juno as his wife. His love for his mistress was always transient. This was partly because of the status of Juno among the gods and goddesses. Most importantly, Males needed a legal wife to manage his family and have legal descendants to inherit his properties. At that time, lots of people separated marriage from love. Love was not necessarily the basis for marriage. [6] Jove couldn't dominate his marriage completely at his will. Marriage should be the balance of benefits and relationship while love was based on sex and impulse. This was the reason why marriage should be relatively stable and love was passionate but temporary.

\section{CONCLUSION}

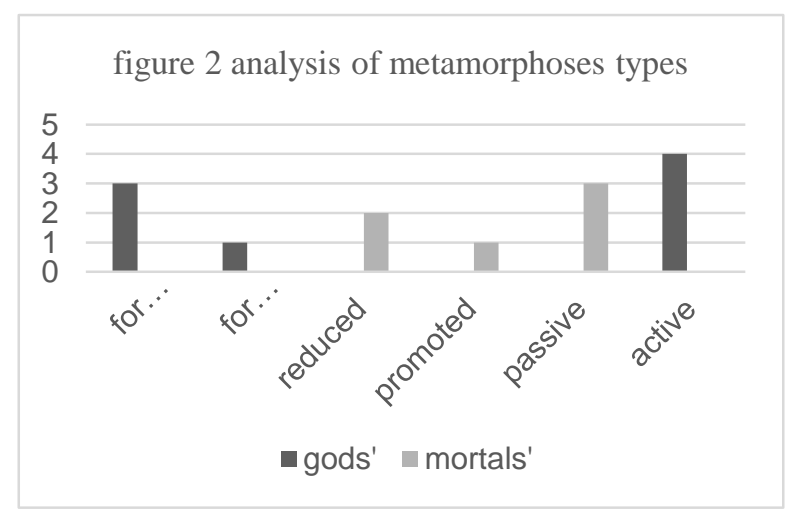

The 4 transformations of gods symbolized the means of those powerful to get what they wanted, which were all active while 3 metamorphoses of mortals were about existence situation, which were all passive. From these facts, we can infer the arbitrariness of the gods and the helplessness of mortals.

Revenges of Juno on her rivals in love reflects females' jealousy in their defence of marriage under the authority of husband. People's pursuit of chastity and stable marriage can be seen in these revenge stories.

\section{REFERENCES}

[1] V. Shklovsky, Prose Theory. Trans. Z.C. Liu, Nanchang: Baihuazhou Literature and Arts Press, 1997.

[2] [Rome] Ovid: Metamorphoses[M], translated by Horace Gregory, NY: Signet Classic Printing, 2009

[3] Y.P. Ma: Pursuit and Exploration-on the Transformation in Western Literature, Master Thesis, Hangzhou: Zhejiang Normal University, 2010, P2-3

[4] J. H. Hu, The feminist Conscience Shown by the Females in Greek Myths, Journal of Chongqing Technical College, Philosophy and social sciences, 2010, (3)

[5] Z. D. Zheng, The Myths and Legends of Greece and Rome, Shanghai: Shanghai Bookstore Publishing House, 2000: 3

[6] Y. Z. Zheng, The Value of Love of the Greek in Myths and Reality, Huhhot: Master Thesis, Inner Mongolia University, 2011: 27 